\title{
Analisis Kemanfaatan Budaya Berbahasa Inggris Pada Sektor Pariwisata Berkelanjutan Di Era Industri 4.0
}

\author{
Yayu Anggraeini Katili ${ }^{1}$, Ansar Sahabi ${ }^{2}$, I Kadek Satria Arsana ${ }^{3}$, Sulasmi ${ }^{4}$ \\ ${ }^{1}$ Program Studi Ilmu Administrasi Negara, Universitas Bina Taruna Gorontalo \\ Email: anggraini.yayu@gmail.com \\ 2 Program Studi Ekonomi Syariah, IAIN Sultan Amai Gorontalo \\ Email: ansar.sahabi@gmail.com \\ ${ }^{3}$ Program Studi Ilmu Administrasi Bisnis, Universitas Bina Taruna Gorontalo \\ Email: satriaarsana28@gmail.com \\ ${ }^{4}$ Program Studi Ilmu Administrasi Bisnis, Universitas Bina Taruna Gorontalo \\ Email: lasmiayu1@gmail.com
}

\begin{abstract}
English has an important role in the sustainable tourism sector through communication media with the aim of promoting abroad, service, good communication between foreign tourists and tourism actors, and the surrounding community which ultimately relates to the development of local tourism progress in the sustainable tourism sector in the industrial era. 4.0. Tourist actors must master English, especially the surrounding community, namely simple conversation, mastery of language and basic conversation. This study aims to examine the Benefits of English-Speaking Culture in the Sustainable Tourism Sector in the Industrial Era 4.0 in Gorontalo Province. The analytical method used is descriptive qualitative analysis. This paper shows that English-speaking culture in the sustainable tourism sector in the industrial era 4.0 in Gorotalo Province is needed with the aim of increasing foreign tourist visitors, facilitating communication using English and also as a promotional event abroad about local tourist destinations in the Province. Gorontalo. English has an important role in the tourism sector as a basis for people around tourist destinations and those who work in the tourism industry to be able to communicate well using English.
\end{abstract}

Keywords : Sustainable Tourism; Destinations; Industry 4.0; Culture; English.

Abstrak. Bahasa Inggris memiliki peran penting dalam sektor pariwisata berkelanjutan melalui media komunikasi dengan tujuan sebagai promosi ke luar negeri, pelayanan, komunikasi yang baik wisatawan asing dengan pelaku wisata, dan masyarakat sekitar yang pada akhirnya berhubungan dengan pengembangan kemajuan wisata lokal pada sektor pariwisata berkelanjutan di era industri 4.0. Pelaku wisata harus mengusai Bahasa Inggris terutama masyarakat sekitar yakni percakapan sederhana, penguasaan bahasa dan percakapan dasar. Penelitian ini bertujuan mengkaji Kemanfaatan Budaya Berbahasa Inggris Pada Sektor Pariwisata Berkelanjutan di Era Industri 4.0 di Provinsi Gorontalo. Metode analisis yang digunakan adalah analisis kualitatif deskriptif. Tulisan ini menunjukkan bahwa budaya berbahasa Inggris pada sektor pariwisata berkelanjutan di era industri 4.0 di Provinsi Gorotalo sangat diperlukan dengan tujuan untuk meningkatkan pengunjung wisatawan asing, memperlancar komunikasi dengan menggunakan Bahasa Inggris dan juga sebagai ajang promosi ke luar negeri tentang destinasi wisata lokal yang ada di Provinsi Gorontalo. Bahasa Inggris memiliki peranan penting dalam sektor pariwisata sebagai dasar bagi masyarakat sekitar destinasi wisata dan yang bekerja di industri pariwisata agar mampu berkomunikasi dengan baik menggunakan Bahasa Inggris.

Kata Kunci : Pariwisata Berkelanjutan; Destinasi; Industri 4.0; Budaya; Bahasa Inggris. 


\section{PENDAHULUAN}

Indonesia memiliki kekayaan alam yang sangat melimpah. Keindahan alam dan budayanya sangat berpotensi untuk dikembangkan secara berkelanjutan, (Romarina, A, 2016). Keragaman suku di Indonesia yang ada disetiap provinsi melahirkan banyak budaya adat istiadat, (Ismawardi, I, 2019), seperti Bali yang terkenal dengan sebutan pulau dewata. Begitu juga dengan keindahan laut Wakatobi yang terkenal dengan surga nyata bawah laut, (Hijrah, W. O. 2014). Sehingga hal ini menjadi daya tarik tersendiri bagi wisatawan asing untuk melakukan perjalanan wisata dengan salah satu tujuan wisata yaitu Indonesia. Selain itu, keindahan alam di Indonesia juga dapat dinikmati sepanjang tahun. Pengembangan pariwisata pada setiap daerah perlu menjadi perhatian bersama oleh para pemangku kepentingan untuk meningkatkan devisa, (Dewi, M, 2016).

Sumbangan devisa oleh sektor pariwisata dari tahun 2016 sampai dengan tahun 2018 selalu meningkat. Peningkatan yang cukup signifikan terjadi di tahun 2018 yakni sebesar 16.426 Miliar US Dolar. Sedangkan ditahun 2016 adalah 11.206 Miliar US Dolar dan tahun 2017 sumbangan devisa sektor pariwisata adalah sebesar 13.139 Miliar US Dolar, (BPS Indonesia, 2018). Perkembangan sektor pariwisata di Indonesia cukup pesat, bahkan Indonesia mampu mengalahkan Thailand dan Sri Lanka.

Pengembangan sektor pariwisata dengan baik dapat dijadikan salah satu alat dalam meningkatkan pendapatan asli daerah melalui cara mengelola destinasi dan mengeksplorasi secara intens potensi-potensi wisata yang dimiliki daerah. Selain itu, melakukan promosi yang juga merupakan faktor utama dalam mendukung kemajuan dan meningkatkan kunjungan wisata. Penyediaan dan pembenahan infrastruktur pendukung juga sangat dibutuhkan. Pada zaman modern (di era industri 4.0) bukan merupakan perkara sulit dalam melakukan ajang promosi. Adanya kemajuan teknologi semakin mempermudah masyarakat atau pun wisatawan asing dalam mengakses informasi-informasi destinasi wisata yang menarik untuk melakukan perjalanan wisata, (Heliany, I., 2019). Namun, disatu sisi dengan adanya kemajuan teknologi menjadi persaingan ketat di era globalisasi. Apabila masyarakat tidak mampu menghadapi maka akan tergilas oleh kemajuan tersebut. Selain itu, dalam menghadapi persaingan global masyarakat sebagai pelaku industri pariwisata dituntut juga mengusai bahasa internasional yaitu bahasa inggris, (Damayanti, L. S., 2019). Sebab, setiap negara memiliki bahasa resmi sebagai alat pemersatu bangsa yang berbeda dengan negara lain. Bahasa digunakan sebagai media komunikasi antara satu dengan yang lainnya. Dengan adanya bahasa mempermudah masyarakat berinteraksi.

Era industri 4.0 teknologi informasi dan komunikasi (TIK) bahasa merupakan sarana komunikasi yang membantu dalam kehidupan berbagai bidang termasuk dalam dunia pariwisata. Di zaman sekarang menjadi suatu kebutuhan mendasar dalam sebuah organisasi, perusahaan, instansi pemerintah dan instansi pendidikan. Budaya berbahasa Inggris memberikan manfaat yang baik pada era teknologi informasi dan komunikasi dalam dunia pariwisata sebagai sarana dan prasarana dalam mempromosikan pariwisata yang sering kita dengar secara elektronik dengan nama digital marketing, (Warmayana, I. G. A. K., 2018).

Era industri 4.0 di Provinsi Gorontalo, pemerintah menjadikan pariwisata sebagai salah satu sektor andalan dan fokus perhatian. Hal ini terjadi karena sektor ini manjanjikan nilai tambah ekonomi yang sangat tinggi. Dalam upaya memajukan pariwisata, pemerintah melakukan berbagai usaha diantaranya dengan meningkatkan mutu pelayanan pariswisata dan peningkatan kualitas pada bidang-bidang yang berkaitan dengan kepariwisataan. Cara yang dilakukan antara lain dengan melakukan promosi pariwisata, mengusahakan daya tarik objek wisata seperti sarana transportasi dan akomodasi.

Permasalahan yang dihadapi pelaku-pelaku industri pariwisata di Indonesia khususnya Gorontalo adalah keterampilan penggunaan bahasa inggris masih minim. Hal ini menjadi salah satu kendala dalam menjual destinasi wisata di Gorontalo dan juga menyulitkan wisatawan asing melakukan interaksi untuk mendapatkan informasi-informasi seputaran tentang sejarah destinasi wisata yang disuguhkan. Pengembangan pariwisata berkelanjutan sangat bergantung pada pengelolaan yang membutuhkan sumber daya manusia kapabel dibidangnya yang tidak hanya 
mengusai teknik marketing akan tetapi mampu menjadi guide serta mampu mengusai bahasa inggris untuk berkomunikasi dengan para wisatawan asing. Melihat pentingnya berbahasa Inggris dalam dunia pariwisata, perlu adanya penelitian terkait Analisis Kemanfaatan Budaya Berbahasa Inggris Pada Sektor Pariwisata Berkelanjutan Era Industri 4.0 di Provinsi Gorontalo.

\section{METODE PENELITIAN}

Penelitian ini dilakukan di Provinis Gorontalo dengan pertimbangan Provinsi Gorontalo merupakan salah satu Provinsi yang memiliki destinasi wisata yang potensial untuk dikembangkan lebih lanjut. Pendekatan yang digunakan dalam penelitian ini adalah deskriptif kualitatif. Dengan fokus penelitian yang akan dijadikan sebagai tolok ukur kajian penelitian adalah Meningkatkan kunjungan Wisatawan Asing, Memperlancar Komunikasi Berbahasa Inggris dan Ajang Promosi Budaya Lokal. Sumber data primer dalam penelitian diperoleh melalui hasil wawancara berupa tanggapan dan jawaban informan (Kepala Dinas Pariwisata Provinsi Gorontalo, Stake Holder terkait bergerak di bidang pariwisata, Pramuwisata dan juga masyarakat sekitar destinasi wisata). Sumber data sekunder diperoleh dari dokumentasi yang diambil di lokasi penelitian.

Dalam penelitian ini pemilihan informan sebagai sumber data diperoleh melalui teknik purposive sampling. Informan dalam penelitian ini yaitu Kepala Dinas Pariwisata Provinsi Gorontalo, Stake Holder terkait bergerak di bidang pariwisata, Pramuwisata dan juga masyarakat sekitar destinasi wisata.

Metode pengumpulan data dalam peneltian ini dikakukan melalui Observasi yang dilakukan dengan mengunjungi langsung Kantor Pariwisata Provinsi Gorontalo untuk melakukan pengamatan dan pencatatan secara sistematis dalam rangka mengetahui kemanfaatan budaya Berbahasa Inggris pada sektor Pariwisata berkelanjutan di era industry 4.0. Wawancara dengan mengumpulkan data melalui pertanyaan secara lisan kedapada informan yang telah ditentukan. Dokumentasi dengan pengumpulan data melalui bahan yang berupa gambar ataupun tulisan yang ada di lokasi penelitian yang berhubungan dengan variable yang diteliti.

Adapun teknik analisis data yang digunakan dalam penelitian ini adalah Pengumpulan data. Peneliti mengumpulkan data dengan cara melakukan wawancara kepada informan. Penyajian data. Data yang diperoleh peneliti dari hasil wawancara kemudian ditampilkan dalam bentuk teks naratif yang bahasanya telah diubah ke bahasa yang lebih ilmiah. Penarikan Kesimpulan. Data yang telah ditampilkan dalam bentuk teks naratif kemudian dikaji sesuai dengan teori yang digunakan dalam penelitian ini untuk kemudian ditarik kesimpulan.

\section{HASIL PENELITIAN DAN PEMBAHASAN}

a. Tren Kunjungan Wisata Manca Negara dan Tingkat Hunian Kamar

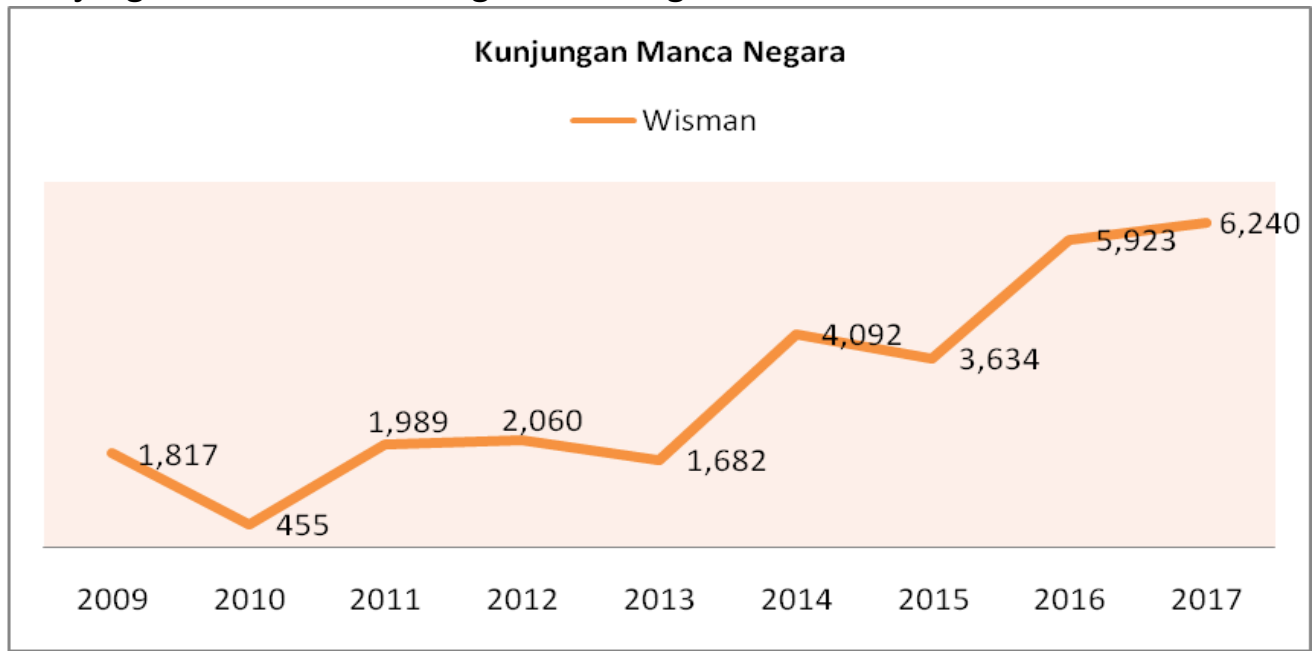

Grafik 1. Tren Kunjungan Wisata Manca Negara 
Berdasarkan grafik diatas dapat dilihat bahwa di Provinsi Gorontalo selama tahun 2009 sampai dengan tahun 2017 kunjungan wisata manca negara mengalami fluktuatif. Namun pada tahun 2016 sampai dengan tahun 2017 data pada grafik menunjukkan bahwa kunjungan wisata manca negara mengalami peningkatan. Meningkatkanya kunjungan wisatawan di Gorontalo dipengaruhi oleh faktor kekayaan dan keindahan pemandangan alamnya serta keragaman suku dan budaya dimiliki oleh daerah dengan julukan kota serambi madinah ini.

Selain itu, dukungan pemerintah terhadap pengembangan destinasi wisata di Gorontalo sangat gencar dilaksanakan mengingat Gorontalo merupakan daerah yang sangat potensial untuk ditumbuh kembangkan destinasi wisatanya. Letak Gorontalo yang juga sangat strategis berada diantara Provinsi Sulawesi Tengah dan Provinsi Sulawesi Utara sangat menguntungkan sebagai rute penghubung atau rute yang dilewati oleh wisata manca negara di kedua provinsi tersebut.

Dukungan pemerintah tertuang pada peraturan daerah Provinsi Gorontalo nomor 4 tahun 2011 mengenai rencana tata ruang wilayah atau RTRW yang menetapkan beberapa kawasan yang potensi untuk ditumbuh kembangkan sebagai kawasan pariwisata di Gorontalo. Kawasan tersebut tersebar di berbagai kecamatan dan kabupaten di Gorontalo seperti destinasi wisata benteng otanaha di Kecamatan Kota Barat Kota Gorontalo, wisata bahari Olele di Kecamatan Bilongala Kabupaten Bone Bolango, destinasi pulau Saronde di Kabupaten Gorontalo Utara, Wisata Tradisional Torosiaje Kecamatan Popayato Kabupaten Pohuwato dan destinas-destinasi wisata lainnya.

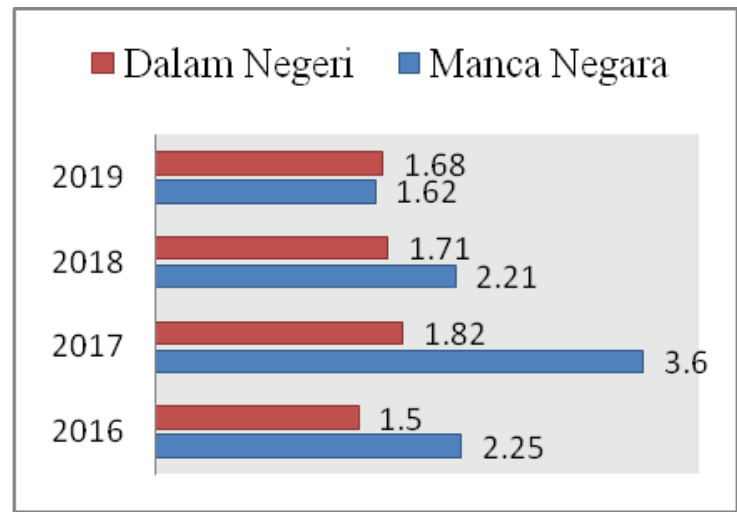

(a)

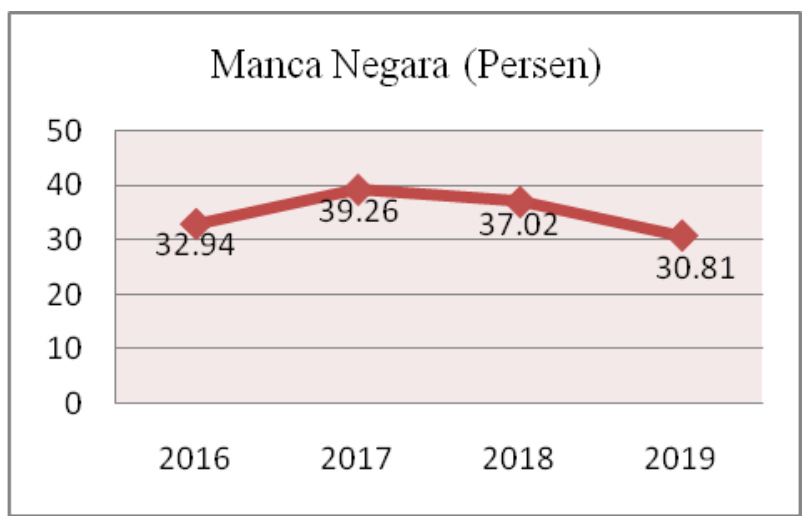

(b)

\section{Grafik 2. (a) Rata-Rata Lama Menginap \& (b) Tingkat Hunian Kamar}

Dari grafik 2. a, dapat dijelaskan bahwa kunjungan wisatawan asing maupun domestik yang menginap di Provinsi Gorontalo tergolong singkat. Dari tahun 2016 rata-rata menginap adalah 3 hari dan tahun 2017 meningkat menjadi 4 hari. Namun di tahun 2018 rata-rata wisatawan asing yang menginap di Gorontalo adalah 3 hari dan tahun 2019 mengalami penurunan menjadi rata-rata 2 hari.

Sejalan dengan rata-rata lama menginap wisatawan asing maupun wisatawan domestik, tingkat hunian kamar juga mengalami fluktuatif. Akomodasi yang tersedia 100 persen hanya terpakai 32.94 persen pada tahun 2016 dan tahun 2017 mengalami peningkatan menjadi 39.26 persen. Akan tetapi dari tahun 2018 sampai dengan tahun 2019 tingkat hunian kamar di Gorontalo mengalami penurunan.

Apabila melihat data 2017, rata-rata lama menginap dan tingkat hunian kamar dengan jumlah kunjungan wisata baik wisatawan asing maupun wisatawan domestik yakni 785.969 orang dengan tingkat hunian yang hanya 39.26 persen mengindikasikan bahwa ketersediaan akomodasi di Gorontalo sangat memadai. Meskipun secara agregat ketersediaan akomodasi tersebut tersebar diseputaran Kota Gorontalo.

\section{b. Peranan Berbahasa Inggris Pada Sektor Pariwisata}

Bahasa Inggris salah satu bahasa resmi internasional yang diakui oleh PBB memiliki kontribusi yang sangat penting dalam dunia industri pariwisata terutama dalam media komunikasi. Ketika 
seseorang berkomunikasi dengan wisatawan asing yang mempunyai bahasa yang berbeda maka penguasaan bahasa asing sangatlah perlu, agar dalam berkomunikasi bisa saling memahami maksud dan tujuan komunikasi. Dalam hal pelayanan wisata, wisatawan asing datang ke Indonesia merupakan tamu yang harus dilayani, sehingga pelaku wisata adalah pelayan yang harus melayani tamu yang datang. Sebab itulah dalam komunikasi dengan wisatawan mancanegara yakni, pelaku wisata yang ada di tempat wisata khususnya masyarakat Provinsi Gorontalo sekitar destinasi wisata harus menguasai Bahasa Inggris, agar dapat berkomunikasi dengan baik serta melayani wisatawan yang berkunjung.

Kemampuan dalam penguasaan Bahasa Inggris pada dasarnya merupakan proses komunikasi yang dibutuhkan saat berkomunikasi dengan wisatawan asing. Sehingga peranan Bahasa Inggris dalam meningkatkan jumlah pengunjung wisatawan asing sangat berpengaruh terutama dari segi pelayanan, salah satu promosi wisata ke luar negeri, reservasi, pelayanan akomodasi (perjalanan dan hotel), pelayanan saat guiding, komunikasi wisatawan dengan masyarakat.

Pelaku pariwisata di Provinsi Gorontalo rata-rata masyarakat yang melakukan pelayanan ada beberapa yang dapat berkomunikasi dengan lancar dengan wisatawan asing, dikarenakan memang menguasai Bahasa Inggris, ada pula yang masih belum lancar yakni masyarakat sekitar yang melakukan komunikasi dengan para wisatawan dengan Bahasa Inggris yang dasarnya saja. Sebagian para wisatawan juga menggunakan pemandu bahasa Indonesia yang menguasai Bahasa Inggris untuk membantu dalam melakukan perjalanan ke tempat-tempat wisata yang dikunjungi.

Bahasa inggris tidak hanya diperlukan pada saat komunikasi pada dunia pariwisata. Tataran dan tantangan globalisasi juga tidak kalah pentingnya mengusai bahasa inggris. Sebab bahasa inggris bahasa yang sangat strategis. Ketika wisatawan asing yang datang dari berbagai penjuru dunia datang dengan tujuan melakukan perjalanan wisata maka bahasa ibu atau bahasa negara asal pada umumnya kurang membantu di negara lain sebagai negara tujuan wisata. Sehingga bahasa inggris memiliki peran penting disini sebagai bahasa komunikasi dikancah internasional. Untuk itu, masyarakat provinsi Gorontalo khususnya pada sektor pariwisata seharusnya betul-betul menguasai Bahasa Inggris sebagai media komunikasi antara kedua bela pihak agar dapat meningkatkan kunjungan wisatawan asing.

Sejalan dengan hasil penelitian dari Galela (2014) menyatakan bahwa peranan bahasa inggris di Tobelo sangat penting dalam mendukung komunikasi dan memberikan pelayanan kepada tamu asing yang berkunjung di Tobelo. Olehnya meningkatkan kemampuan masyarakat dalam penggunaan bahasa inggris perlu dibelajarkan kepada para pelaku industri pariwisata atau pramuwisata, (Zulkarnain, 2016). Selain itu, masyarakat juga perlu diberikan pelatihan dalam meningkatkan kapasitas penguasaan bahasa inggris. Seperti penelitian dari (Febriani, dkk, 2019) dalam menghadapi perkembangan zaman untuk dapat ikut bersaing di era industri 4.0 penting dilakukan bimbingan teknis dan pelatihan-pelatihan untuk masyarakat sebagai bekal dilapangan sehingga masyarakat atau pelaku pariwisata memiliki kepercayaan diri dalam menghadapi tantangan global.

Bahasa Inggris, selain memiliki peran sebagai media komunikasi juga merapukan pemersatu. Bahasa Inggris memiliki peran dalam menghubungkan semua orang tanpa mengenal latar belakang orang-orang tersebut. Di sektor pariwisata Provinsi Gorontalo dimana masyarakat menyatakan bahwa Bahasa Inggris adalah medium bagi para wisatawan asing dan para pelaku industri wisata di mana dapat dikatakan sebagai bahasa pergaulan atau pengantar bagi orang-orang yang ada disekitar obyek wisata dengan berbagai bahasa terutama pada tempat wisata.

\section{c. Memperlancar Bahasa Inggris Bagi Pelaku Pariwisata}

Penguasaan Bahasa Inggris sangat penitng meskipun terdapat beberapa tempat wisata atau hotel, Bahasa Inggris tidak dijadikan alat komunikasi secara terus menerus. Sebagian tempat wisata atau hotel tidak menjadikan Bahasa Inggris untuk berkomunikasi sehari-hari, maka Bahasa Inggris dapat dibagi menjadi 2, yakni ocassionally, dan rarely (Erazo et al., 2019). Ocassionally adalah dimana Bahasa Inggris hanya digunakan pada waktu tertentu saja, sedangkan rarely merupakan 
Bahasa Inggris yang jarang digunakan. Hal ini mengakibtakan bahwa daerah tujuan wisata bukan merupakan daerah tujuan wisata bagi wisatawan asing, tentu pelaku wisata hanya berkomunikasi dengan wisatawan lokal yang memiliki bahasa yang sama yakni bahasa Nasional.

Selain itu, pelaku pariwisata yang berinteraksi langsung dengan wisatawan asing, di mana masyarakat provinsi Gorontalo yang ada di sekitar tempat wisata bisa diajak berkomunikasi oleh wisatawan asing. Apabila ada pemandu dalam berkomunikasi tentu tidak menjadi masalah, namun masyarakat sekitar juga bisa berkomunikasi menggunakan Bahasa Inggris, sehingga ini dianggap hal postif dan akan memberi kesan luar biasa kepada wisatawan, meskipun yang digunaka adalah bahasa sederhana.

Penguasaan Bahasa Inggris bagi pelaku pariwisata adalah penting adanya dalam hal media komunikasi antara wisatawan dan pelaku pariwisata. Apabila menguasai Bahasa Inggris dalam dunia pariwisata, maka dapat memberikan kebermanfaatan, yaitu dapat meningkatkan kepuasan para wisatawan, memotivasi wisatawan intenasional bahwa penguasaan dalam berkomunikasi menggunakan Bahasa Inggris tentu akan mampu meningkatkan minat wisatawan internasional untuk berkunjung dan akan menjadih lebih efektif. Penguasaan Bahasa Inggris akan sangat membantu membantu memahami kebutuhan wisatawan dengan lebih baik, artinya adanya komunikasi yang baik, maka segala keperluan dan kebutuhan wisatawan dapat dipahami dan diatasi. Dengan adanya komunikasi yang baik tentu dapat memahami budaya lain melalui dialog antara wisatawan dan pelaku pariwisata.

Masyarakat sekitar tempat wisata harus mengatahui dan menguasai Bahasa Inggris, minimal dasar-dasar Bahasa Inggris, kosa kata yang sederhana dalam berkenalan, atau hanya sekedar menyapa para wisatawan asing untuk menjaga agar dapat memahami semua komunikasi yang terjalin dengan wisatawan asing tanpa terjadi kesalahpahaman. Dengan menguasai Bahasa Inggris, para pelaku wisata akan memahami budaya wisatawan asing dan mampu memberikan pelayanan yang maksimal serta mampu memberikan kesan bahkan citra yang baik sehingga memiliki pengaruh dalam meningkatkan kemajuan indsutri pariwisata yang ada di Provinsi Gorontalo.

\section{d. Ajang Promosi Budaya Lokal}

Untuk memperkenalkan pariwisata dalam negeri terutama pariwisata lokal ke negara lain ada beberapa cara yang bisa dilakukan. Kemajuan teknologi informasi saat ini adalah hal yang utama yang digunakan untuk melakukan promosi melalui dunia maya dan merupakan hal paling efektif dalam memperkenalkan wisata lokal ke manca negara. Caranya adalah menggunakan promosi melalui berbasis internet (web) berbahasa Inggris yang merupakan bahasa Internasional. Adanya web ini maka kapan saja dan di mana saja wisatawan asing mampu mengaksesnya. Akan tetapi jika melakukan promosi melalui dunia maya harus dilengkapi dan diperjelas serta bisa mendesainnya semenarik mungkin. Berdasarkan penelitian bahwa sektor pariwisata Provinsi Gorontalo dapat mengembangkan potensi destinasi wisata melalui ajang promosi. Promosi yang dilakukan tidak lain adalah untuk membuat objek wisata yang dimaksud mempunyai daya tarik wisatanya dan lebih dikenal lagi oleh calon wisatawan untuk mengunjungi dan menikmati tempatnya.

Sektor pariwisata saat ini berlomba-lomba membuat serta menciptakan produk yang bervariasi sesuai dengan pembangunan pariwisata, produk yang dimaksud yakni, memperkenalkan keindahan alam, budaya maupun adat istiadat yang beraneka ragam maupun keunikan yang terdapat pada objek wisata tersebut Seperti flora dan fauna maupun ekosistem termasuk keindahan alam.

Era teknologi yang dikenal sekarang Revolusi indutrri 4.0 merupakan salah satu solusi pada sektor pariwisata dalam meningkatkan daya saing di Indonesia yang cukup relevan. Selama beberapa tahun kedepan permintaan dan penawaran pariwisata memiliki potensi yang cukup besar. Di era industri 4.0 ini dapat memanfaatkannya dengan berbagai bentuk sebagai ajang promosi.

Pelayanan informasi mengenai pariwisata menggunakan Bahasa Inggris, dikarenakan Bahasa Inggris merupakan bahasa global yang pertama digunakan oleh etnis mancanegara dari manapun 
asalnya. Oleh karena itu penggunaan Bahasa Inggris menjadi sebuah alasan bagi pelaku pariwisata dalam dunia kepariwisataan sangatlah penting menggunakan Bahasa Inggris.

Menurut pengamatan dari beberapa toko masyarakat kawasan destinasi wisata di Provinsi Gorontalo sudah ada sebagian yang mampu menggunakan Bahasa Inggris terutama yang menggeluti di bidang pariwisata dalam hal memberikan pelayanan dan informasi kepada wisatawan dengan media komunikasi yang sesuai dengan wisatwan asing yakni komunkasi dengan berbahasa Inggris. Dengan demikian tentu ini sangat membantu masyarakat dan pemerintah dalam mengembangkan profesionalisme di bidang kepariwisataan untuk mendorong terwujudnya pemanfaatan budaya berbahasa Inggris pada sektor pariwisata berkelanjutan di era indusri 4.0. (Kawatak, S. Y., Walansendow, Y. A., \& Repi, D. N. (2020).

\section{KESIMPULAN}

Berdasarakan pembahasan di atas tentang kebermanfaatn budaya berbahasa Inggris pada sektor pariwisata berkelanjutan di era industri 4.0 di Provinsi Gorontalo dapat disimpulkan bahwa bahasa inggris memiliki manfaat yang baik bagi pelaku industri pariwisata. Penggunaan bahasa inggris yang baik mampu meningkatkan kepercayaan tamu asing untuk datang ke Gorontalo. Hal ini dikarenakan para tamu mudah melakukan komunikasi dan pelayanan untuk mendapatkan informasi seputaran destinasi yang dikunjungi sesuai dengan kebutuhan dan keinginan wisatawan asing. Penggunaan bahasa inggris dalam melakukan promosi juga sangat dibutuhkan. Pelaku-pelaku industri pariwisata sangat dituntut untuk mengusai Bahasa asing minimal bahasa inggris untuk dapat memberikan pelayanan serta kepuasan kepada wisatawan asing yang nantinya akan meningkatkan pendapatan sektor pariwisata sebagai perkembangan serta kemajuan destinasi wisata lokal khususnya di Provinsi Gorontalo. Harapannya bahasa asing atau bahasa inggris untuk pelaku-pelaku industri pariwisata khususnya di Gorontalo dapat ditingkatkan melalui pelatihan-pelatihan yang diselenggarakan oleh pemerintah sebagai salah satu upaya mendukung pengembangan sektor pariwisata berkelanjutan. Potensi wisata yang melimpah dan infrastruktur yang memadai tanpa dibekali dengan sumber daya manusia yang kapabel akan sangat susah mewujudkan pariwisata berkelanjutan di Provinsi Gorontalo.

\section{DAFTAR PUSTAKA}

Badan Pusat Statistik. 2018. Jumlah Devisa Sektor Pariwisata. https://bps.go.id/indikator/indikator/view_data/0000/data/1160/sdgs 8/1. diakses tanggal 19 September 2021

Damayanti, L. S. (2019, December). Menilik Peranan Dan Pentingnya Keterampilan Berbahasa Inggris Dalam Industri Pariwisata. In Journey (Journal of Tourismpreneurship, Culinary, Hospitality, Convention and Event Management) (Vol. 2, No. 1, pp. 71-82).

Dewi, M. (2016). Pengembangan Paket Wisata Untuk Wisatawan Iran Yang Ditangani Pt. Ceria Tours \& Travel-Bali. http://stp-bandung.net:8080/repository/handle/123456789/91

Erazo, M. A. C., Ramirez, S. I. M. (2019). English Language Skills Required by the Hospitality and Tourism Sector in El Oro, Ecuador. Theory and parctice in Language Studies.

Febriani, R. B., Rustandi, A., \& Sugiarto, B. R. (2019). Meningkatkan kemampuan bahasa Inggris anak dan remaja pra-sejahtera untuk mendukung kegiatan pariwisata situ Lengkong Panjalu. Abdimas Galuh, 1(1), 94-98.

Galela, D. (2014). Peranan Bahasa Inggris Di Bidangindustri Pariwisata Di Tobelo. Jurnal Elektronik Fakultas Sastra Universitas Sam Ratulangi, 1(01).

Heliany, I. (2019). Wonderful Digital Tourism Indonesia Dan Peran Revolusi Industri Dalam Menghadapi Era Ekonomi Digital 5.0. Destinesia: Jurnal Hospitaliti Dan Pariwisata, 1(1), 21-35.

Hijrah, W. O. 2014. Pengembangan Bahan Belajar Mandiri Mulok Berbasis Lingkungan Pesisir Anakanak Nelayan di Kepulauan Tukang Besi Kabupaten Wakatobi. Selami, 2(40), 221348. 
Ismawardi, I. (2019). Syari'at Islam Dalam Lingkup Keberagaman Masyarakat Aceh. BIDAYAH: STUDI ILMU-ILMU KEISLAMAN, 165-182.

Kawatak, S. Y., Walansendow, Y. A., \& Repi, D. N. (2020). Strategi Pengembangan Pariwisata Berkelanjutan di Danau Mooat Sulawesi Utara dengan Menggunakan Analisis SWOT. Lensa Ekonomi, 11(01), 1-12.

Romarina, A. (2016). Economic Resilience Pada Industri Kreatif Gunamenghadapi Globalisasi Dalam Rangka Ketahanan Nasional. Jurnal Ilmu Sosial, 15(1), 35-52.

Warmayana, I. G. A. K. (2018). Pemanfaatan digital marketing dalam promosi pariwisata pada era industri 4.0. Pariwisata Budaya: Jurnal IImiah Agama Dan Budaya, 3(2), 81-92.

Zulkarnain, N. S. 2016. Peranan Bahasa Inggris Dalam Pengembangan Objek Dan Daya Tarik Wisata Di Kabupaten Jember. https://repository.unej.ac.id/handle/123456789/77922 